\title{
Debittering of Protein Hydrolysates by Lactobacillus LBL-4 Aminopeptidase
}

\author{
Bozhidar Tchorbanov, Margarita Marinova, and Lydia Grozeva \\ Institute of Organic Chemistry with Centre of Phytochemistry, Bulgarian Academy of Sciences, Acad. G. Bonchev Str. 9, \\ 1113 Sofia, Bulgaria \\ Correspondence should be addressed to Bozhidar Tchorbanov, tchorban@orgchm.bas.bg
}

Received 4 May 2011; Revised 28 June 2011; Accepted 30 June 2011

Academic Editor: Alane Beatriz Vermelho

Copyright () 2011 Bozhidar Tchorbanov et al. This is an open access article distributed under the Creative Commons Attribution License, which permits unrestricted use, distribution, and reproduction in any medium, provided the original work is properly cited.

\begin{abstract}
Yoghurt strain Lactobacillus LBL-4 cultivated for $8-10 \mathrm{~h}$ at $\mathrm{pH} \sim 6.0$ was investigated as a considerable food-grade source of intracellular aminopeptidase. Cell-free extract manifesting $>200 \mathrm{AP}$ U/l was obtained from cells harvested from $1 \mathrm{~L}$ culture media. Subtilisin-induced hydrolysates of casein, soybean isolate, and Scenedesmus cell protein with degree of hydrolysis 20-22\% incubated at $45^{\circ} \mathrm{C}$ for $10 \mathrm{~h}$ by $10 \mathrm{AP} \mathrm{U} / \mathrm{g}$ peptides caused an enlarging of $\mathrm{DH}$ up to $40-42 \%, 46-48 \%$, and 38-40\% respectively. The DH increased rapidly during the first $4 \mathrm{~h}$, but gel chromatography studies on BioGel P-2 showed significant changes occurred during 4-10 h of enzyme action when the DH increased gradually. After the digestion, the remained AP activity can be recovered by ultrafiltration (yield 40-50\%). Scenedesmus protein hydrolysate with DH $20 \%$ was inoculated by Lactobacillus LBL-4 cells, and after $72 \mathrm{~h}$ cultivation the $\mathrm{DH}$ reached $32 \%$. The protein hydrolysates (DH above $40 \%$ ) obtained from casein and soybean isolate (high $Q$ value) demonstrated a negligible bitterness while Scenedesmus protein hydrolysates (low $Q$ value) after both treatments were free of bitterness.
\end{abstract}

\section{Introduction}

During the enzymatic hydrolysis of proteins (especially with high $Q$ value [1]), bitter-taste peptides are released limiting their application in food processing. Methods for elimination of bitter peptides are known, but the procedures cause a significant loss of essential amino acids $[2,3]$. Exopeptidases from different sources have been applied for additional hydrolysis of protein hydrolysates reducing the bitter taste. Kidney's tissue aminopeptidase [4] as well as pancreatic protease preparations [5] have been involved in the debittering procedures of different originate peptides. Enzymes from plant origin have been successfully used for this purpose [6-8]. The bitterness of casein hydrolysate as well as of soybean protein hydrolysate has been removed at low cost with incubation by cell wall Saccharomyces carboxypeptidases [9]. Similar effect has been observed during the additional hydrolysis of peptides catalyzing by fungal protease preparation [10]. A number of commercial microbial aminopeptidases have been in use for preparation of protein hydrolysates lacking bitter taste [11-14].
Special attention was given to aminopeptidases hydrolyzing bitter peptides and liberating aromatic amino acids, which are important precursors of aroma compounds [1517]. Enzymes hydrolyzing single Pro or pairs of Pro residues in bitter peptides are of particular interest [17-20]. Because of its unusual structure, the proline residue is resistant to enzymatic hydrolysis by exopeptidases and oftentimes limits the depth of hydrolysis that can be achieved. The use of proline-specific peptidases together with aminopeptidases of broad specificity has been especially successful in the food industry [21].

A basic review on bitterness in cheese due to the partial casein hydrolysis was published in 1996 [22]. The lactic acid bacteria expressing specific X-prolyl dipeptidylpeptidase is also being explored for debittering of tryptic digests and enzyme-modified cheese [23]. A similar approach has also been used for the generation of bioactive peptides with antihypertensive, immunomodulatory, and antimicrobial properties [24].

Exopeptidase activities have been detected in the number of lactic acid bacteria, but their role has been described in 


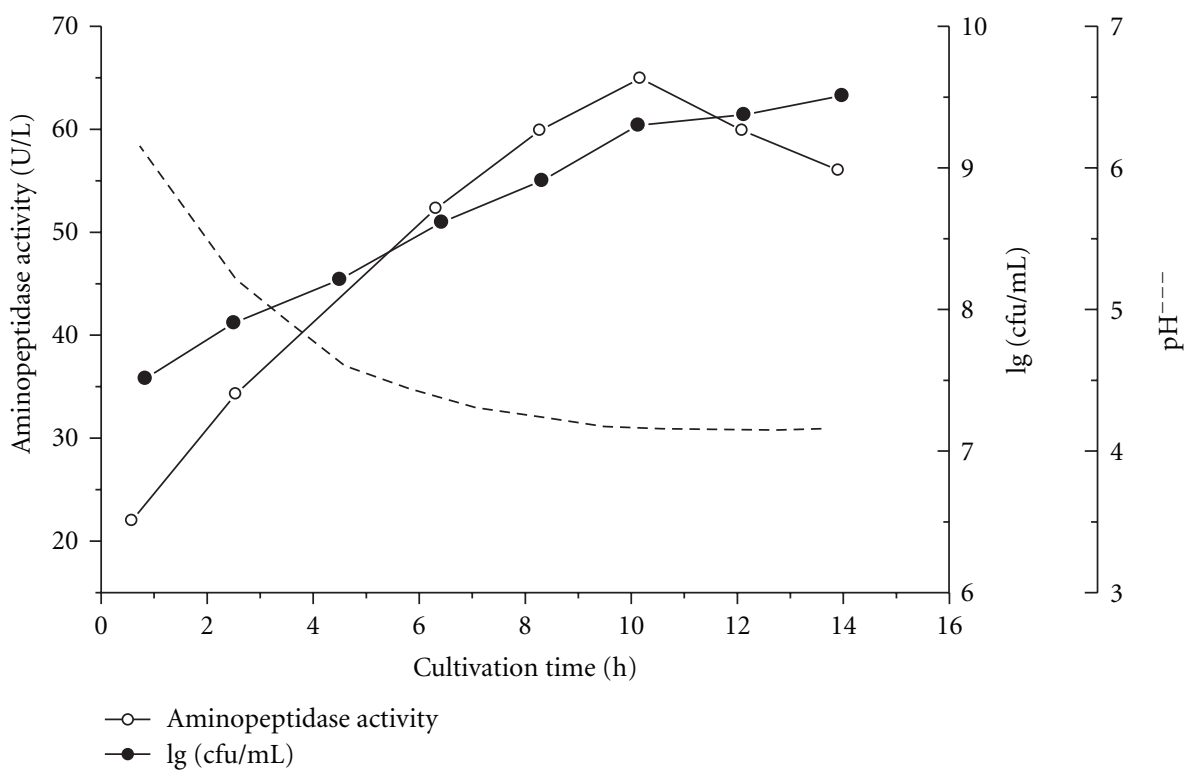

FIGURE 1: Biosynthesis of intracellular aminopeptidase activity during the Lactobacillus LBL-4 cultivation at natural pH decrease; (o): aminopeptidase activity; $(\bullet): 1 \mathrm{~g} \mathrm{cfu} / \mathrm{ml}$.

respect mainly to the dairy processes $[24,25]$. Lactobacillus LBL-4 strain from yoghurt starters was reported as a source of intracellular AP activity [26]. The aim of the present work is to study: (i) Lactobacillus LBL-4 as a source of AP activity depending on the fermentation conditions, (ii) the additional cleavage and corresponding debittering of hydrolysates from casein, soybean (high $Q$ value), as well as Scenedesmus cell protein (low $Q$ value) in vitro by cell-free AP extract, (iii) hydrolysis in vivo during the cultivation of the strain LBL-4 on a medium based on the protein hydrolysate from Scenedesmus cells.

\section{Experimental Procedures}

2.1. Aminopeptidase Extract. The strain Lactobacillus LBL4 was obtained from the ELBY Engineering Lactic Acid Bacteria Collection, Sofia, Bulgaria. A 10\% (v/v) inoculum of the working culture LBL-4 was added to a medium based on hydrolyzed milk proteins [27] in a fermenter LKB 1601 Ultroferm, and temperature was maintained at $45^{\circ} \mathrm{C}$ for $14 \mathrm{~h}$.

The cultivation was conducted using two different ways-at natural $\mathrm{pH}$ decrease through the lactic acid fermentation as well as at pH5.9 \pm 0.1 maintained by automatic addition of neutralizer containing $20 \% \mathrm{Na}_{2} \mathrm{CO}_{3}$ in $20 \% \mathrm{NH}_{4} \mathrm{OH}$. In both cases, the culture was stirred with $\mathrm{T}$-line stirrer at $150 \mathrm{rpm}$. Microbial growth was determined by measuring absorbance at $650 \mathrm{~nm}$. Viable cell population was estimated by plating samples on MRS agar. Lactobacillus LBL- 4 cells were harvested from the medium samples by centrifugation $\left(4000 \times \mathrm{g}\right.$ at $4^{\circ} \mathrm{C}$ for $\left.15 \mathrm{~min}\right)$. The addition of lysozyme (Sigma) $\left(1 \mathrm{mg} / \mathrm{mL}\right.$ at $40^{\circ} \mathrm{C}$ for $\left.2 \mathrm{~h}\right)$ led to AP release. The pooled supernatant fluids $\left(4000 \times \mathrm{g}\right.$ at $4^{\circ} \mathrm{C}$ for $30 \mathrm{~min}$ ) of four successive centrifugations gave the AP extracts, concentrated further by ultrafiltration on Amicon UM-10 membrane.

2.2. Hydrolysis. Solutions (6\%) of casein and soybean isolate as well as $10 \%$ suspension of green algae Scenedesmus extracted by ethanol were used as substrates [28]. The enzymatic hydrolysis by subtilisin DY (5000 units/g substrate protein) was carried out at $\mathrm{pH} 7.8$ and $50^{\circ} \mathrm{C}$ for $4 \mathrm{~h}$ [29]. After hydrolysis, the reaction mixtures were centrifuged at $2000 \times \mathrm{g}$ for 15 minute yielded in clear solutions (pH 7.0) containing 3.6\% hydrolyzed protein with $\mathrm{DH}$ 20-22\% (casein, soybean) and 19-20\% (algae). Samples $(100 \mathrm{~mL})$ of protein hydrolysate solutions were incubated at $45^{\circ} \mathrm{C}$ with cell-free AP extract (36 AP units), and the additional hydrolysis in vitro was run for $10 \mathrm{~h}$. Aliquots were taken, adjusted to $\mathrm{pH} 3.0$ to obtain, clear solution, filtered, and applied for analysis. After the process was over $(10 \mathrm{~h})$, some samples of the reaction mixture were subjected to ultrafiltration (Amicon UM-10 membrane) to evaluate the enzyme recovery. In order to study the enzyme/substrate ratio, hydrolysis for $10 \mathrm{~h}$ of both casein and algae peptides were performed in the range of 5-20 AP units/g hydrolyzed protein. Industrial scale Scenedesmus algae protein hydrolysate [28] was extracted by water $(1: 9$, w/v) to obtain clear solution (DH 19-20\%; 5.5\% hydrolyzed protein). Peptides were inoculated by $10 \%(\mathrm{v} / \mathrm{v})$ culture of Lactobacillus LBL-4 grown in sterilized skim milk $\left(10^{7}\right.$ $10^{8} \mathrm{cfu} / \mathrm{mL}$ ) and fermented for $72 \mathrm{~h}$ at $45^{\circ} \mathrm{C}$ in order to follow the in vivo hydrolysis.

2.3. Analysis. Aminopeptidase activity of the cell-free LBL-4 extract was analyzed using L-Ieucine-p-nitroanilide (Serva) as substrate [30]. A unit of AP activity was defined as the 


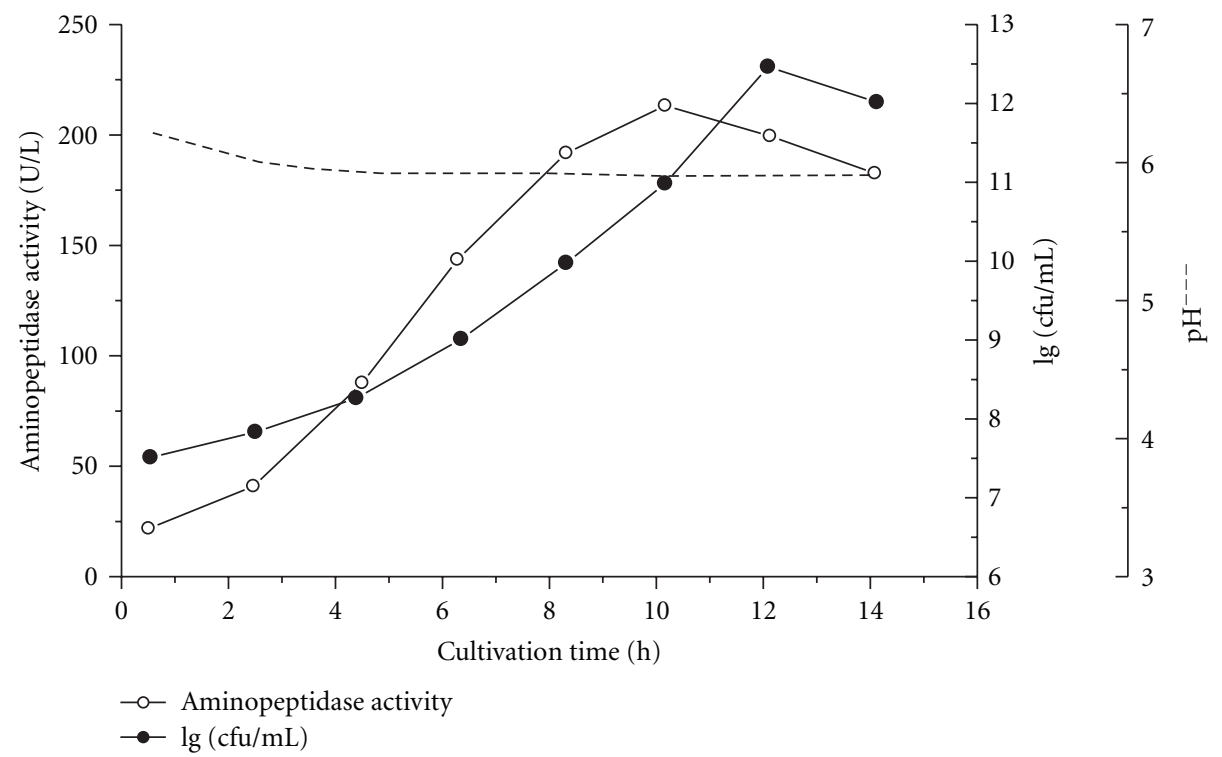

Figure 2: Biosynthesis of intracellular aminopeptidase activity during the Lactobacillus LBL-4 cultivation at maintained pH $\sim 6.0$; (o): aminopeptidase activity; $(\bullet): 1 \mathrm{~g} \mathrm{cfu} / \mathrm{ml}$.

amount of enzyme producing $1 \mu$ mole $p$-nitroaniline per minute $\left(\mathrm{E}_{410}=8800 \mathrm{M}^{-1} \mathrm{~cm}^{-1}\right)$. Carboxypeptidase activity was measured by spectrophotometric method using Ncarbobenzyloxy-L-Leu (Serva) as substrate. One unit of enzymatic activity was defined as the amount of enzyme that produced an increase in absorbance at $570 \mathrm{~nm}$ of 0.01 units [29]. Proteolytic activity of Subtilisin DY was defined as $\mu \mathrm{g}$ tyrosine released per min during the hydrolysis of $1.2 \%$ casein (Fluka) at $\mathrm{pH} 7.4,37^{\circ} \mathrm{C}[31]$.

The concentration of amino nitrogen was determined according to Adler-Nissen [32] and the DH was estimated as the percentage of the cleaved peptide bonds. The protein content was measured by Kjeldahl's method [33].

BioGel P-2 extra fine, from Biorad (USA) was packed in a column $(13 \times 140 \mathrm{~mm})$ equilibrated by $0.1 \mathrm{M}$ acetic acid containing $0.28 \%$ SDS as it was recommended earlier [34]. Samples $(0.1 \mathrm{~mL})$ were applied and eluted (velocity $18 \mathrm{~mL} / \mathrm{h}$ ) by starting buffer. Absorbance at $280 \mathrm{~nm}$ was measured continuously by a monitor UV-l, Pharmacia (Sweden). The following molecular weight markers were applied: Insulin B-chain (Sigma) -3495 Da; L-glutathione (oxidized) (Serva) -612 Da; L-glutathione (reduced) (Serva) -307 Da; Trp-Leu (Merck) -317 Da; Gly (Sigma) -75 Da.

For sensory analysis, the peptide solutions $(0.25 \mathrm{~mL})$ were compared with $0.25 \mathrm{~mL}$ of standard quinine sulfate solutions (0.001-0.004\%) for bitterness. The bitterness level was expressed in corresponding concentration of the quinine sulphate.

\section{Results and Discussion}

3.1. Aminopeptidase Sources. Yoghurt strain Lactobacillus LBL-4 was investigated as a considerable food-grade source of intracellular aminopeptidase using a crude cell extract, because the strain is isolated from traditional yogurt in

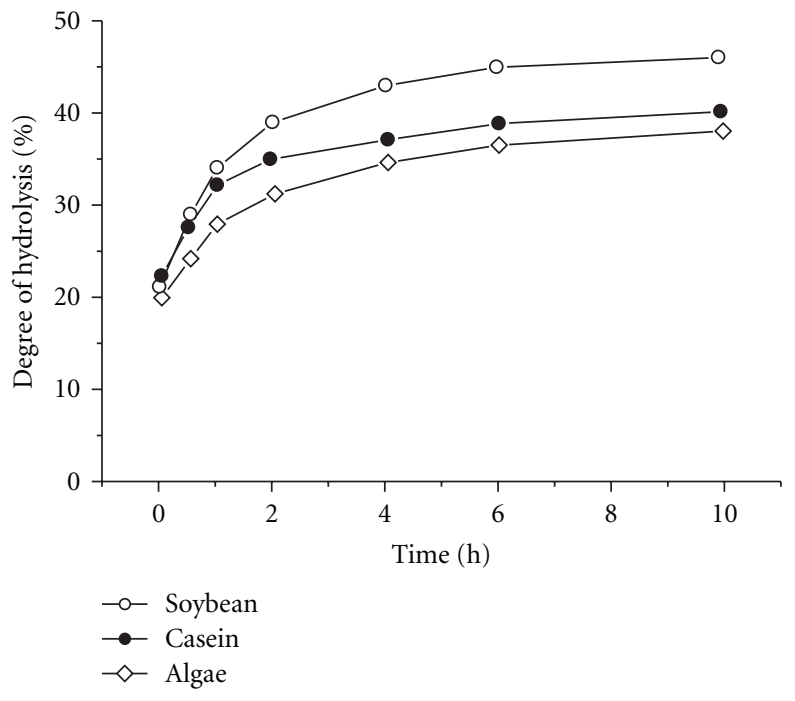

FIGURE 3: Increase of DH during the additional cleavage of protein hydrolysates from soybean $(\mathrm{o})$, casein $(\bullet)$ and algae $(\diamond)$ protein induced by $8 \mathrm{AP} \mathrm{U} / \mathrm{g}$ peptides.

Bulgaria. Further study regarding the isolation and characterization of the aminopeptidase will be published.

Figures 1 and 2 represent the biosynthesis of intracellular AP activity during the cultivation of LBL-4 at maintained $\mathrm{pH}$ 5.8-6.0 as well as at natural $\mathrm{pH}$ decrease down to $\mathrm{pH}$ 4.0. It is clear that the number of living LBL-4 cells $(\mathrm{cfu} / \mathrm{mL})$ as well as their growth phase define the enzyme yield (Figure 2). Cultivation at constant $\mathrm{pH}$ for $12 \mathrm{~h}$ lead to maximal cell density of $5 \times 10^{12} \mathrm{cfu} / \mathrm{mL}$; however, maximal AP activity (>200 AP U/l medium) was yielded from logarithmic-phase cells harvested after $8-10 \mathrm{~h}$ fermentation time. The low AP activity (70 U/l medium) obtained in the case of lactic acid 

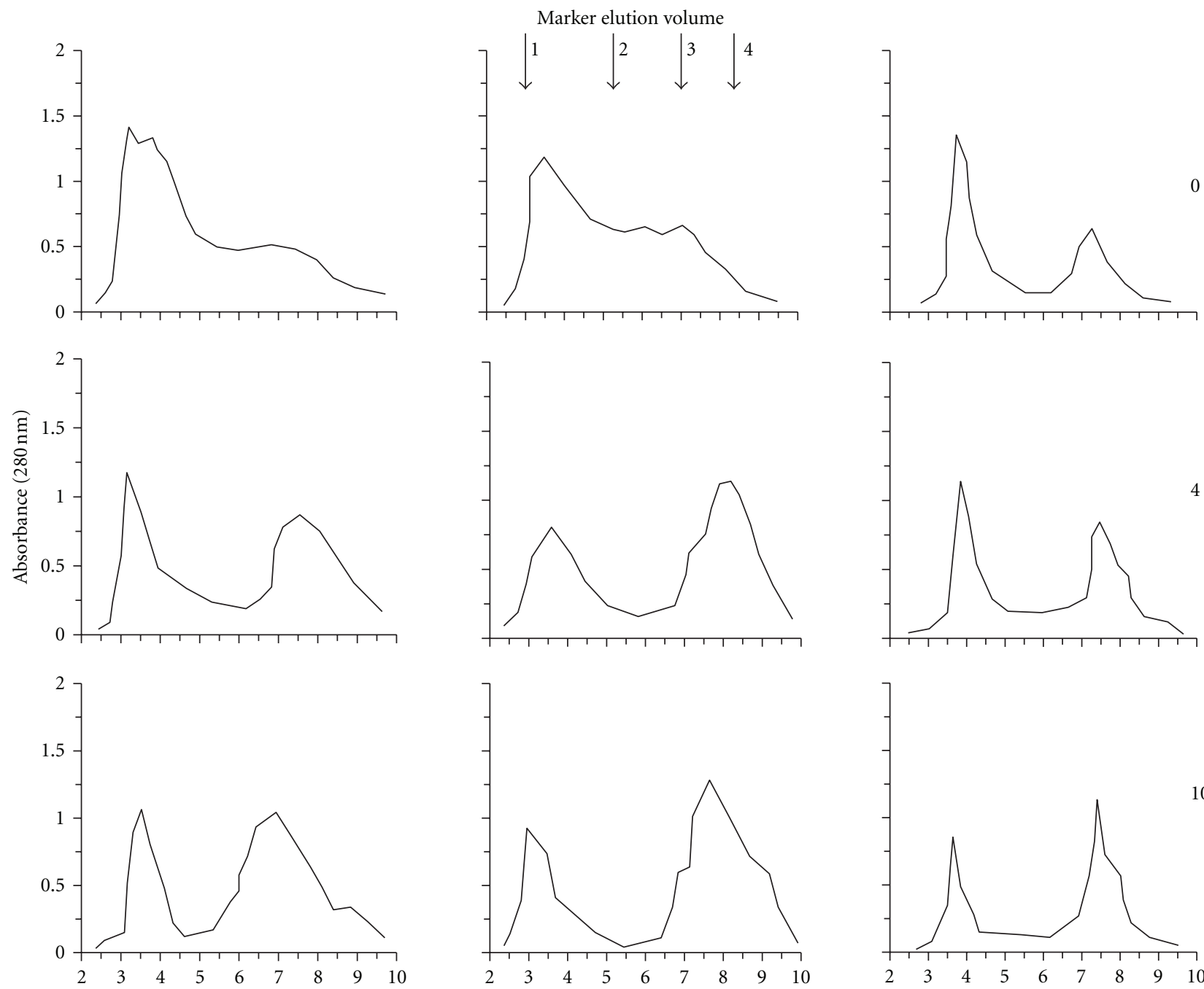

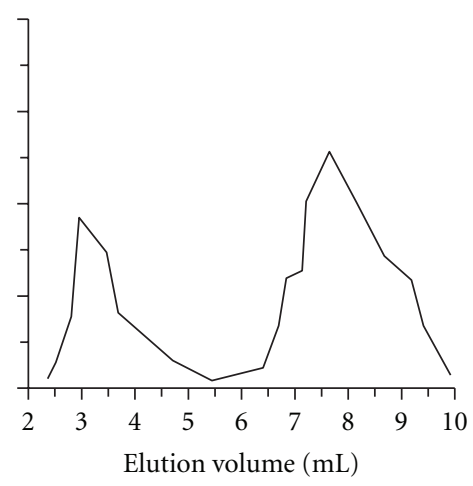

(b)

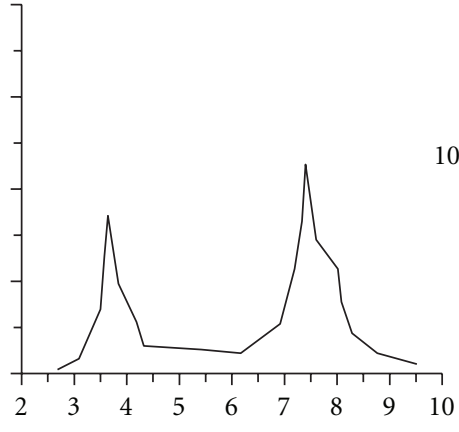

(c)

Figure 4: Gel chromatography on BioGel P-2 of protein hydrolysates from soybean (a), casein (b) and algae (c) obtained during the additional cleavage by $8 \mathrm{AP} \mathrm{U} / \mathrm{g}$ peptides. MW markers were used as follows: (1) Insulin B chain (3495 Da); (2) L-glutation (oxidized) (612 Da); (3) Trp-Leu (317 Da); (4) Gly (75 Da).

fermentation at maintained $\mathrm{pH} \sim 6.0$ (Figure 2) underlined the importance of $\mathrm{pH}$ control during the cultivation process. The obtained extract can be subjected to evaporation in vacuum, and no activity reduction was observed using up to $45^{\circ} \mathrm{C}$ of the water bath. An ultrafiltration procedure can also be applied successfully. Neither endopeptidase nor carboxypeptidase activities were detected in the cell-free extract, which is evidence that the in vitro peptide hydrolysis was due to the action of the aminopeptidase only.

Exopeptidases from different sources have been successfully used for further hydrolysis of bitter peptides. The extracts from animal sources should be purified from the contaminants presented. Mycotoxins make microbial exopeptidases less suitable for food application [6]. The low content of exopeptidases in plant sources as well as laborious procedures for isolation appears to be a limitation for their practical use.

It was discovered that baker's yeast residue autolysis demonstrating carboxypeptidase activity [9] is an attractive exopeptidase source. Cell wall Saccharomyces carboxypeptidase has been caused fate of peptides bitterness $(200 \mathrm{~g}$ cell walls/kg peptides). According to our studies, the use of yeast residues can be accompanied by microbial contamination, so the presence of preservatives could be required during the hydrolytic process.

The strain Lactobacillus LBL-4 is an attractive microbial source of AP from several points of view: (a) the culture is used for production of traditional food; (b) relatively high 


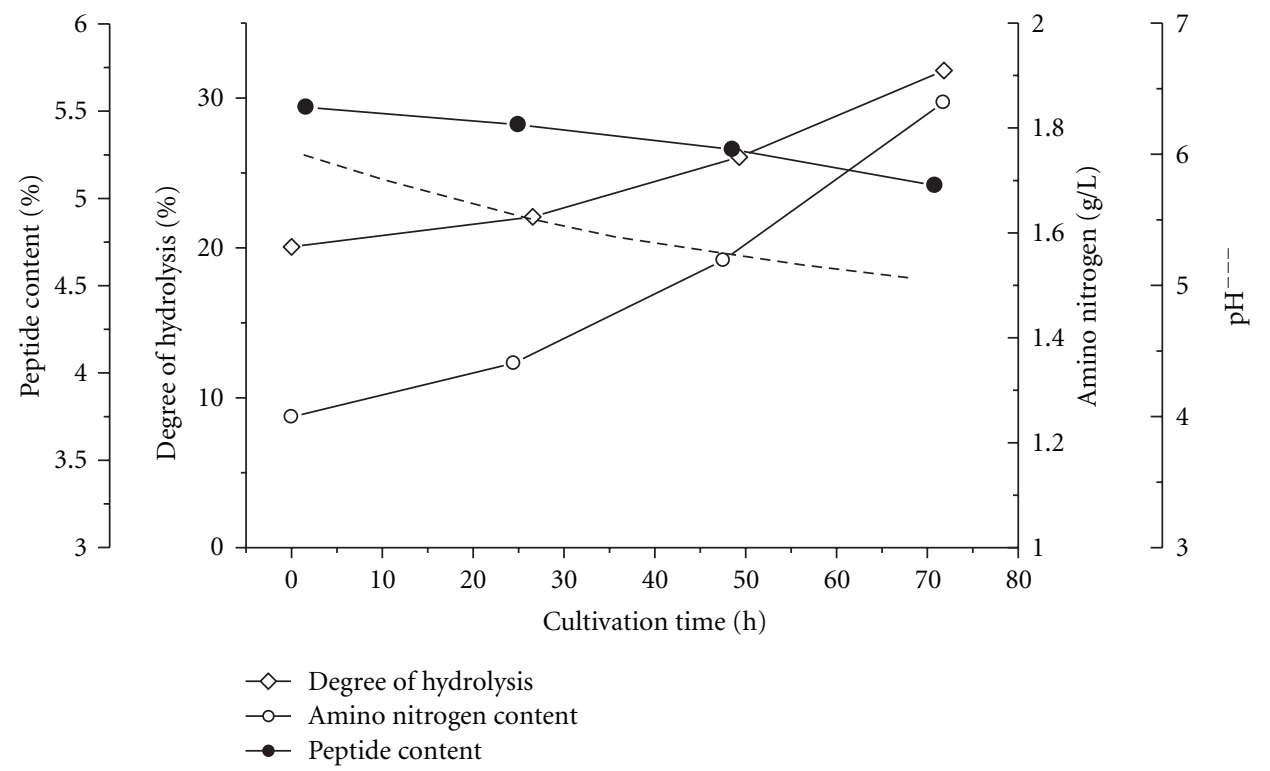

FIGURE 5: Additional hydrolysis of Scenedesmus protein hydrolysate during the Lactobacillus LBL-4 fermentation. ( $\diamond)$ : degree of hydrolysis; (o): amino nitrogen content; $(\bullet)$ : peptide content.

level of AP activity after short fermentation time, (c) after sterile filtration the hydrolysis can be carried out in aseptic conditions; (d) possibility for industrial-scaled cultivation.

3.2. Hydrolysis by Cell-Free Aminopeptidase. The enzymic protein hydrolysates used as model substrates for additional hydrolysis by AP activity were obtained after subtilisininduced hydrolysis of casein, soybean isolate, as well as Scenedesmus cell protein as described before [28]. In all cases, the enzymatic hydrolysis proceeded to a limited DH (20$26 \%$ ) although a proteolytic enzyme with broad specificity was used. This result could be explained by the formation of relatively stable polypeptide structures, containing in their interior some peptide bonds unsusceptible to the enzyme action [35]. On the other hand, it is known that casein hydrolysates (with high $Q$ value) as well as soybean isolate hydrolysates with $\mathrm{DH} 20-26 \%$ manifest a strong bitterness [36].

The influence of enzyme/substrate ratio was studied using the initial protein hydrolysates from casein (DH 20 $22 \%)$ and algae protein (18-20\%). Algae peptides were additionally degraded by 5,10 , and $20 \mathrm{AP} \mathrm{U/g}$ hydrolyzed protein, obtaining final products with $\mathrm{DH} 32 \%, 38 \%$, and $43 \%$ respectively. Subtilisin-digested casein incubated at the same enzyme/substrate ratio resulted in hydrolysates with DH $34 \%, 40 \%$, and $46 \%$. A range of 8-10 AP U/g hydrolyzed protein could be recommended for the debittering process combining an acceptable $\mathrm{DH}$ of the final products and enzyme save. The subtilisin activity prior to addition of the AP activity was not inactivated due to two reasons: (a) minimum chemical introduction in food process, and (b) the enzyme continues its action on the new peptides formed under the AP action.
Figure 3 illustrates the additional cleavage of protein hydrolysates with different $Q$ value by AP cell-free extract from LBL-4. A significant increase of DH during the first $4 \mathrm{~h}$ of additional hydrolysis process corresponded to a typical enzyme kinetic. After $10 \mathrm{~h}$ the process was ended, and the initial DH (20-22\%) increased up to $40-42 \%, 46-48 \%$, and $38-40 \%$ for the casein, soybean, and algae proteins, respectively. No significant differences in $\mathrm{DH}$ were observed at similar experiments carried out for up to $24 \mathrm{~h}$ hydrolysis.

The enzyme action was followed by gel chromatography (Figure 4) showing that considerable changes occurred during the hydrolysis in the period of 4 to $10 \mathrm{~h}$ when the DH increased gradually. The gel chromatography on BioGel P-2 was applied by addition of $0.28 \%$ SDS reducing the interactions of hydrophobic aromatic amino acids (resp. their short peptides) and matrix [34]. This gave us an opportunity to follow the reaction according to the molecular weights of the released peptides. Gel chromatography profiles demonstrates 3 main fractions: (i) relatively highMW peptides (2000 Da and more); (ii) middle fraction consisting of 3-8 amino acid residues mainly; (iii) dipeptides and free amino acids. Practically, oligopeptides consisting of 2 to 8 amino acid residues appeared to be substrates for the aminopeptidase's action during the additional hydrolysis. After the end of hydrolysis, a reduction of the middle fraction can be observed in all cases, and the final hydrolysates obtained consist mainly of high MW fraction and free amino acids. The presence of high MW peptides in the hydrolysates is a positive factor balancing high osmolarity of the free amino acids. After the AP treatment, samples of the hydrolysates (casein, algae) were subjected to ultrafiltration showing $40-50 \%$ enzyme recovery with possibility for reuse.

The bitterness level of the initial soybean and casein hydrolysates (high $Q$ value [1]) was near to the bitterness 
of $0.003-0.004 \%$ quinine sulphate. After the additional AP hydrolysis, the bitter taste reduced significantly and was comparable with $0.0005-0.001 \%$ quinine sulphate (near to the threshold). Even the debittering effect was very clear, the number of panelists (5 people) makes these results with preliminary character. The algae protein hydrolysate (low $Q$ value [28]) manifesting a weak bitter taste was practically free of bitterness after the additional cleavage by AP.

3.3. Hydrolysis during the Lactobacillus LBL-4 Fermentation. The results obtained during the hydrolysis in vitro by Lactobacillus LBL-4 AP challenged us to check the possibility for cleavage of the bitter peptides during the strain fermentation. The cultivation of Lactobacillus LBL-4 on algae protein hydrolysate-a model peptide system with low $Q$ valueis followed on Figure 5. During the in vivo process, DH of algae hydrolysate increased to a more moderate level of $32 \%$, while at the hydrolysis by cell-free AP, the DH reached $38 \%$ (Figure 3 ). The cultivation/hydrolysis time was much longer due to three reasons, mainly, (i) The AP content in the studied model system is approximately in an order less than in the hydrolysis experiments in vitro; (ii) the cell membrane limited the permeability of peptides; (iii) although the substrate solution has buffering capacity, $\mathrm{pH}$ value of the cultivation medium decreased gradually due to the released lactic acid. On the other hand, the presence of organic carboxylic acids is desirable due to their masking effect on the bitter taste [37].

During the fermentation process, the peptide content decreased (Figure 5) in the range of $10 \%$ from the initial value which was acceptable for a $72 \mathrm{~h}$ process. The final algae peptide solution was nonbitter; therefore, the additional hydrolysis in vivo could be recommended in the case of-low $Q$ value proteins.

\section{Conclusion}

The strain Lactobacillus LBL-4 is an attractive microbial source of aminopeptidase with high potential for debittering of enzymatic protein hydrolysates, which could be successfully applied as food additives in medicine and sport. Both methods: the use of cell-free enzyme extract as well as cultivation of the strain on media containing hydrolyzed protein resulted in a significant reduction of bitterness.

\section{Abbreviations}

$\mathrm{AP}^{1}$ : Aminopeptidase

$\mathrm{DH}^{2}$ : Degree of hydrolysis.

\section{Acknowledgment}

The authors thank the National Foundation for Scientific Research for the financial support of Project TK-X 1608.

\section{References}

[1] K. H. Ney, "Aminosaure-Zusammensetzung von proteinen und die bitierkeil ihrer peptide," Zeitschrift für LebensmittelUntersuchung und -Forschung, vol. 149, pp. 321-323, 1972.

[2] B. Pedersen, "Removing bitterness from protein hydrolysates," Food Technology, vol. 48, no. 10, pp. 96-99, 1994.

[3] S. B. Lin, L. P. Nelles, C. T. Cordle, and R. L. Thomas, "Debittering casein hydrolysates with octadecyl-siloxane (C18) columns," Journal of Food Science, vol. 62, no. 4, pp. 665-670, 1997.

[4] K. M. Clegg and A. D. McMillan, "Dietary enzymatic hydrolysates with reduced bitterness," Journal of Food Technology, vol. 9, pp. 21-29, 1974.

[5] M. M. Mullally, D. M. O’Callaghan, R. J. FitzGerald, W. J. Donnelly, and J. P. Dalton, "Proteolytic and peptidolytic activities in commercial pancreatic protease preparations and their relationship to some whey protein hydrolysate characteristics," Journal of Agricultural and Food Chemistry, vol. 42, no. 12, pp. 2973-2981, 1994.

[6] H. Umetsu, H. Matsuoka, and E. Ichishima, "Debittering mechanism of bitter peptides from milk casein by wheat carboxypeptidase," Journal of Agricultural and Food Chemistry, vol. 31, no. 1, pp. 50-53, 1983.

[7] M. Marinova, N. T. K. Cuc, and B. Tchorbanov, "Enzymatic hydrolysis of soy protein isolate by food grade proteinases and aminopeptidases of plant origin," Biotechnology and Biotechnological Equipment, vol. 22, no. 3, pp. 835-838, 2008.

[8] A. A. Premarathne and D. W. Leung, "Characterization of activity of a potential food-grade leucine aminopeptidase from kiwifruit," Enzyme Research, vol. 2010, Article ID 517283, 5 pages, 2010.

[9] Y. Yano, J. Myaguchi, N. Katayasu, Y. Tachibana, and T. Nakamura, JP 49,406 [93 49,406] / 1993.

[10] L. V. Kofoed, M. Fischer, P. M. Nielson, and K. Pømmer, "Method of producing food flavoring agent," US Patent no. 6,024,990, 2000.

[11] V. Delest, L. Edens, J. G. Kortes, and T. J. B Naeye, "Protein hydrolysates," US Patent no. 6,875,456, 2005.

[12] M. Monod, R. Stocklin, and E. Grouzmann, "Novel fungal proteins and nucleic acids encoding same," US Patent no. 7,468,267, 2008.

[13] A. Blinkovski, K. Brown, and E. Golightly, "Methods of producing protein hydrolysates," US Patent no. 6,465,209, 2002.

[14] N. Izawa, K. Tokuyasu, and K. Hayashi, "Debittering of protein hydrolysates using Aeromonas caviae aminopeptidase," Journal of Agricultural and Food Chemistry, vol. 45, no. 3, pp. 543-545, 1997.

[15] D. E. J. W. Basten, P. J. T. Dekker, and P. J. Schaap, "Aminopeptidase $\mathrm{C}$ of Aspergillus niger is a novel phenylalanine aminopeptidase," Applied and Environmental Microbiology, vol. 69, no. 2, pp. 1246-1250, 2003.

[16] M. Marinova, A. Dolashki, F. Altenberend, S. Stevanovic, W. Voelter, and B. Tchorbanov, "Purification and characterization of L-phenylalanine aminopeptidase from chick-pea cotyledons (Cicer arietinum L.)," Protein and Peptide Letters, vol. 16, no. 2, pp. 207-212, 2009.

[17] M. Marinova, A. Dolashki, F. Altenberend, S. Stevanovic, W. Voelter, and B. Tchorbanov, "Characterization of an aminopeptidase and a proline iminopeptidase from cabbage leaves," Zeitschrift fur Naturforschung C, vol. 63, no. 1-2, pp. 105-112, 2008. 
[18] K. Tishinov, S. Petrova, and P. Nedkov, "Prolyl iminopeptidase from seeds of sunflower (Helianthus annuus L.)," Acta Physiologiae Plantarum, vol. 32, no. 1, pp. 211-213, 2010.

[19] N. Li, J. M. Wu, L. F. Zhang, Y. Z. Zhang, and H. Feng, "Characterization of a unique proline iminopeptidase from whiterot basidiomycetes Phanerochaete chrysosporium," Biochimie, vol. 92, no. 7, pp. 779-788, 2010.

[20] T. Byun, L. Kofod, and A. Blinkovsky, "Synergistic action of an X-prolyl dipeptidyl aminopeptidase and a non-specific aminopeptidase in protein hydrolysis," Journal of Agricultural and Food Chemistry, vol. 49, no. 4, pp. 2061-2063, 2001.

[21] P. J. Bouchier, G. O'Cuinn, D. Harrington, and R. J. FitzGerald, "Debittering and hydrolysis of a tryptic hydrolysate of $\beta$-casein with purified general and proline specific aminopeptidases from Lactococcus lactis ssp. cremoris AM2," Journal of Food Science, vol. 66, no. 6, pp. 816-820, 2001.

[22] M. B. Habibi-Najafi and B. H. Lee, "Bitterness in cheese: a review," Critical Reviews in Food Science and Nutrition, vol. 36, no. 5, pp. 397-411, 1996.

[23] M. B. Habibi-Najafi and B. H. Lee, "Debittering of tryptic digests from $\beta$-casein and enzyme modified cheese by x-prolyl dipeptidylpeptidase from Lactobacillus casei, ssp. casei. LLG," Iranian Journal of Science and Technology, Transaction A, vol. 31, no. 3, pp. 263-270, 2007.

[24] Z. F. Bhat and H. Bhat, "Milk and dairy products as functional foods: A review," International Journal of Dairy Science, vol. 6, no. 1, pp. 1-12, 2011.

[25] K. Savijoki, H. Ingmer, and P. Varmanen, "Proteolytic systems of lactic acid bacteria," Applied Microbiology and Biotechnology, vol. 71, no. 4, pp. 394-406, 2006.

[26] B. Tchorbanov, L. Grozeva, and B. Gyosheva, in Proceedings of the Euro Food Chemistry VII, vol. 1, pp. 235-242, Valencia, Spain, September 1993.

[27] M. Kondratenko, K. Mutafova, B. Gyosheva, B. Koleva, and G. Georgiev, Bulgaria Patent no. 93958/1992, 1992.

[28] B. Tchorbanov and M. Bozhkova, "Enzymatic hydrolysis of cell proteins in green algae Chlorella and Scenedesmus after extraction with organic solvents," Enzyme and Microbial Technology, vol. 10, no. 4, pp. 233-238, 1988.

[29] P. Nedkov, M. Bobatinov, M. Shopova, and N. Genov, Communication Department Bulgarian Academy of Science, vol. 9, pp. 443-449, 1976.

[30] M. El Soda and M. J. Desmazeaud, "Peptide hydrolases of the Thermobacterium group. I. Activity measurements in Lactobacillus helveticus, L. acidophilus, L. lactis and L. bulgaricus," Canadian Journal of Microbiology, vol. 28, no. 10, pp. 1181-1188, 1982.

[31] M. L. Anson, "The estimation of pepsin, trypsin, papain and cathepsin with hemoglobin," The Journal of General Physiology, vol. 22, pp. 78-89, 1939.

[32] J. Adler-Nissen, "Determination of the degree of hydrolysis of food protein hydrolysates by trinitrobenzene sulfonic acid," Journal of Agricultural and Food Chemistry, vol. 27, pp. 12561262, 1979.

[33] P. L. Kirk, "Kjeldahl method for total nitrogen," Analytical Chemistry, vol. 22, no. 2, pp. 354-358, 1950.

[34] B. Tchorbanov, I. Iliev, T. Borresen, and J. Adler-Nissen, Communication Department Bulgarian Academy of Science, vol. 12, pp. 45-47, 1991.

[35] P. Nedkov, A. Lilova, and B. Tchorbanov, "Factors limiting the hydrolysis of casein by subtilisin DY," Biological Chemistry Hoppe-Seyler, vol. 368, no. 10, pp. 1321-1325, 1987.
[36] J. Adler-Nissen and H. S. Olsen, "The influence of peptide chain length on taste and functional properties of enzymatically modified soy protein," in Proceedings of the ACS Symposium Series, vol. 92, pp. 125-146.

[37] D. Debroas, N. Depardon, and G. Blanchart, "Study of enzyme activities and physocochemical parameters during hydrolysis of soy peptides by rumen microflora," Journal of Agricultural and Food Chemistry, vol. 78, pp. 453-460, 1998. 

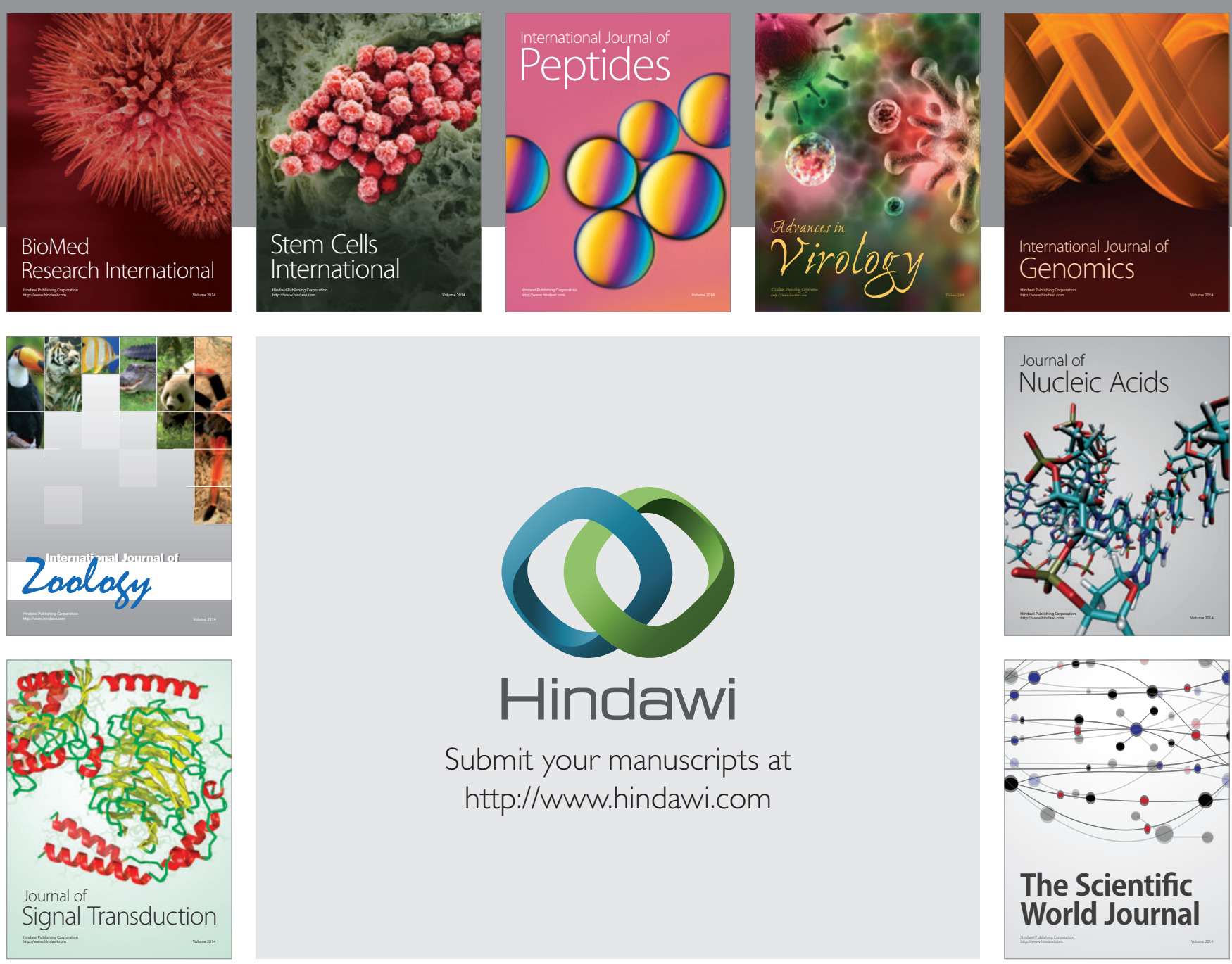

Submit your manuscripts at

http://www.hindawi.com
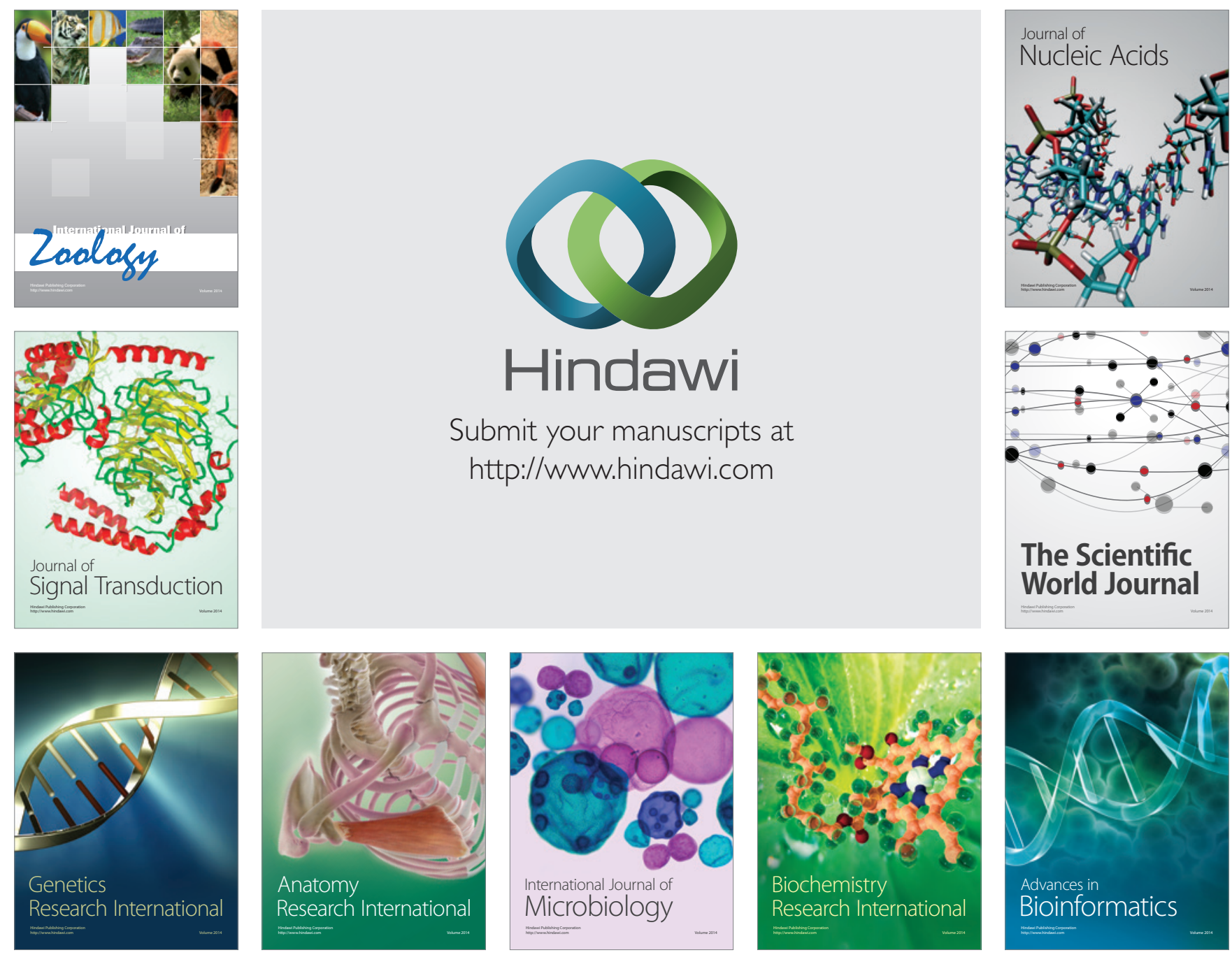

The Scientific World Journal
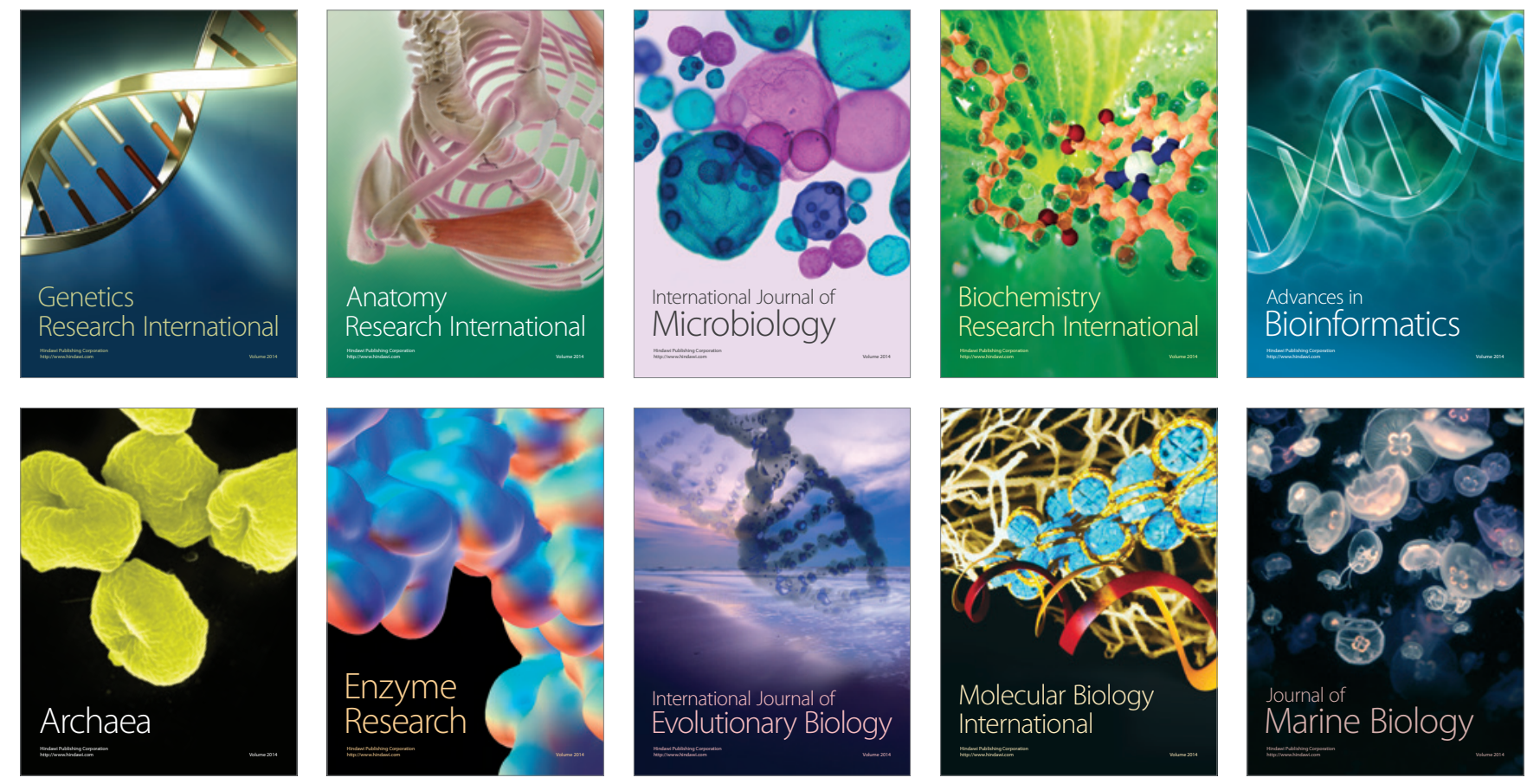